\title{
AN OPEN ONLINE COURSE TO ENHANCE DIGITAL COMPETENCES OF TEACHERS
}

Bengusu UGUR

ORCID: 0000-0002-7588-5857 Department of Computer Education and Instructional Technology

Hacettepe University Ankara, TURKEY

\section{Dr. Selay ARKUN KOCADERE}

ORCID: 0000-0003-4984-6456 Department of Computer Education and Instructional Technology Hacettepe University Ankara, TURKEY

Dr. Pinar NUHOGLU KIBAR

ORCID: 0000-0001-7091-1190 Department of Computer Education and Instructional Technology Hacettepe University Ankara, TURKEY

Dr. Fatma BAYRAK

ORCID: 0000-0001-8500-1456 Department of Computer Education and Instructional Technology Hacettepe University Ankara, TURKEY

Received: 14/07/2020 Accepted: 12/08/2020

\begin{abstract}
The purpose of this study was to design an online professional development program and evaluate the developed course in light of the implementation results. This course provided teachers with the opportunity to develop an ICT-enhanced lesson plan and apply it in their own classes. The current study was conducted using design-based research. Of the 171 teachers registered, 47 participated and 36 completed the full course and received certificates. The self-assessment of the 36 teachers on their ICT-enhanced classroom practices were used in the evaluation of the course. Second, teacher opinions were also solicited via the Teachers' End-of-course Evaluation Questionnaire. Third, the course was evaluated using a rubric by the instructors. According to the results, the self-assessments of teachers on ICT-integration were high. The satisfaction of the teachers with the open online course was also very high, with $97 \%$ recommending the course. The course was evaluated as "exemplary" in terms of Learner Support \& Resources, Online Organization \& Design, and Instructional Design \& Delivery categories, and as "effective" in the rubric's Assessment \& Evaluation of Student Learning, Innovative Teaching with Technology, and Faculty Use of Student Feedback categories. Future implementations could be revised by increasing interaction and feedback and providing additional implementation opportunities for the teachers.
\end{abstract}

Keywords: ICT competencies, open online course, professional development, ICT integration, ICTenhanced lesson plan, teachers' professional development, online course evaluation. 


\section{INTRODUCTION}

Individuals in our emerging knowledge society must have literacy in information and communications technology (ICT), which must be acquired through quality education and teachers equipped to provide technology integration (Gao, Tan, Wang, Wong \& Choy, 2011). In the classroom, technology integration can be defined as the regular use of information and communications technology (ICT) to improve learning. Teachers and their professional development are key elements in this highly complex integration process (Evans, 2006; Herzig, 2004; Hew \& Brush, 2007; Kaya \& Usluel, 2011; Pierson, 2001; Usluel, Mumcu, \& Demiraslan, 2007). Studies have shown that teacher qualifications are one of the most important indicators of the quality and efficiency of education (Ayaz, Oral, \& Soylemez, 2015). Accordingly, teacher competencies and the identification of the qualifications instructors require has become an important area of focus for educational organizations.

The International Society for Technology in Education (ISTE) (2008) identified 20 performance indicators for effective usage of educational technology grouped under five standards: the ability to (1) facilitate and inspire student learning and creativity, (2) design and develop digital age learning experiences and assessments, (3) model digital age work and learning, (4) promote and model digital citizenship and responsibility, and (5) engage in professional growth and leadership.

UNESCO's ICT Competency Framework for Teachers (2011) groups the qualifications expected from teachers into the 3 categories of (1) technology literacy, (2) knowledge deepening, and (3) knowledge creation, each containing six performance indicators. The ICT framework emphasizes that teachers not only should possess and pass on ICT competencies on to their students but that students should also serve as citizens who can show teamwork, problem-solving, and creative thinking skills using ICT.

The European Commission (EC)'s Framework for the Digital Competence of Educators (2017) specified 22 different competencies at 6 different levels: professional engagement, digital resources, teaching and learning, assessment, empowering learners, and facilitating learners. Unlike other frameworks, the EC framework includes learner competencies and the educators' pedagogic competencies along with their professional competencies.

In its study on "Teacher Competencies", the Turkish Education Association (TED) (2009) stated that the transformation in the field of education was related to the knowledge of techno-pedagogy and that teachers require knowledge of teaching pedagogy and field knowledge integrated with technology.

The UNESCO (2011), ISTE (2008), TED (2009), and EC (2017) frameworks agree that teachers must be able to use ICT tools in all stages of the learning-teaching process from planning to evaluation, develop necessary materials for this purpose, create suitable environments, be a model for the learners for the use of technology, and have acquired the competency to use technology in their professional development. Forkosh-Baruch and Avidov-Ungar (2019) highlighted similar points.

Teachers thus require professional development programs that allow them to develop their skills in integrating technology by both improving their existing skills and acquiring new methods to integrate ICT in entirely new ways for learning (Almenara, \& Gimeno, 2019). Several recent studies have emphasized the lack of professional development programs for ICT integration, particularly those that facilitate the interactive sharing of the pros and cons of various classroom practices (Ifinedo, Rikala, \& Hamalainen, 2020). Despite attempts, studies indicate that existing programs have not been entirely successful and often result in teachers integrating technology only as a support to their traditional practices (Blikstad-Balas, \& Klette, 2019).

Furthermore, even teachers who have taken instructional technology courses face serious practical and logistical obstacles while trying to integrate technology into their lessons (So \& Kim, 2009; Usluel, Mumcu \& Demiraslan, 2007). According to Stein, Gurevich, and Gorev (2020), one of the greatest difficulties teachers face in integrating ICT is classroom management. In other words, in professional development courses, teachers are able to master theory and learn the technical aspects of integrating technology but continue to encounter problems in practice. This is believed to be due to the fact that practice requires the ability to analyze the case from a pedagogical perspective which is beyond basic theoretical and technical mastery (Beglau et al., 2011; Usluel, 2016). This important obstacle highlights the necessity of following approaches in professional development programs on ICT integration that facilitate learning through hands- 
on practice and practical experience. Professional development courses which utilize similar ICT that will be used in the classroom and that allow teachers to apply what they have learned increase the success of their ICT integration in the classroom (Hanover Research, 2014, Prestridge, Tondeur, 2015; Tondeur, ForkoshBaruch, Prestridge, Albion, \& Edirisinghe, 2016; Atman, \& Usluel, 2019).

The aim of this study is to design an online professional development program that provides teachers with the opportunity to use technology effectively both within the online course for their own learning and in their classrooms using the tools available to them while teaching and to evaluate their implementation. Four research problems were identified:

(1) What is the best design of an online professional development program that aims to develop skills in integrating technology in education?

(2) What were the teachers' self-assessments on their technology-enhanced lesson implementation within the scope of the designated online course?

(3) What were the teachers' end-of-course evaluations?

(4) What were the instructors' end-of-course evaluations?

\section{METHODS}

The study was carried out using the design-based research method (Barab \& Squire, 2004). Design-based research differs from other research methods in that it removes the sharp boundaries between design and testing by combining theory and practice (Bakker \& van Eerde, 2015). It is used frequently in teacher training studies and has the potential to explain and influence learning and teaching in the natural learning environment (Anderson \& Shattuck, 2012). This method aims to develop interventions (educational products, processes, programs, or policies) that can serve as solutions to practical educational problems based on the theoretical understanding of the learning situation (McKenney \& Reeves, 2012). McKenney \& Reeves (2012) described the way in which design-based research progresses in a flexible and iterative manner through the three core phases of investigation/analysis, design/prototyping, and evaluation/retrospection. The process can be designed through various combinations of the three phases based on the need of the educational problem. The research process can span numerous meso cycles over a long period, in various combinations of these micro cycles, or may be shorter and cover three micro cycles, one from each phase. The process is iterative as the results of some elements in the process affect or enable other targeted elements or phases through repeated attempts. The process can be carried out through different pathways beyond the intended research design. During the research process, the participants are seen as partners, rather than subjects. The participation of researchers in the process, as well as that of practitioners and experts in different subject areas, are suggested in addition to continuous improvement of the design throughout the process (Barab \& Squire, 2004; McKenney \& Reeves, 2012).

The authors served dually as the researchers and the practitioners and conducted the online courses. The process of developing the online course was carried out in line with the educational design research method in a flexible and iterative manner. From the analysis phase to the end of the implementation phase, the research process took approximately one year to complete and consisted of the main stages of analysis, design, development, implementation, and evaluation. Figure 1 outlines the research process, with each stage of the project visualized on the horizontal line and the curved line representing the cycles of the research process. Each small circle on the curve represents sub-outcomes developed in the process. Circles on the curved line, which corresponds between the horizontal line and the expression of the team, mean that it was created in line with the work of that team. The sub-products which were developed in the process that constituted the online course as the main product were visualized on the cycles in detail.

The process was constructed using the people-process-product (P3) framework defined by Khan (2005) as crucial in e-learning project management. The $\mathrm{P} 3$ was also utilized in the visualization of our process (Figure 1). The content, technical, and visual design teams collaborated throughout the process which can be seen from top to bottom of People area. The process was initiated at the analysis stage by a content development team which was actively involved throughout the process. The development process was carried out by a visual design team, technical team, and content development team. 
As can be seen in the more frequent and reversible cycles (Figure 1), the design and development phases, during which the content was structured and the LMS was prepared, were conducted in a more intertwined and iterative manner then the other phases. In order to reach certain saturation on content, formative evaluation was performed at each cycle, with emphasis in the design and development phases (Figure 1).

The conducted formative evaluations by the content team are represented below the horizontal line. Instant course formative evaluation was performed using an interventionist approach based on the participants' responses gathered during the implementation phase which resulted in extension of the course length. In design research, tightly integrated processes of design, evaluation, and revision can enable designers or researchers to identify problems or gaps in the process (Edelson, 2002). Formative evaluation thus holds a significant place in design-based research (Dede, Ketelhut, Whitehouse, Breit, \& McCloskey, 2009; Edelson, 2002). Following the implementation, the participants' and instructors' end of course evaluations were discussed for summative evaluation purposes in the attempt to determine the effectiveness of the course.

The course plan was developed in three cycles in two phases: the first two cycles were part of the analysis phase and the third the design phase. The first version of the course plan was developed at the beginning of the analysis phase was discussed in the study by Ugur and Arkun Kocadere (2016) and the second version of the course plan developed at the end of the analysis phase was summarized in the study by Arkun Kocadere (2017). The current study discusses the entire process with a focus on the Implementation and Evaluation phases.

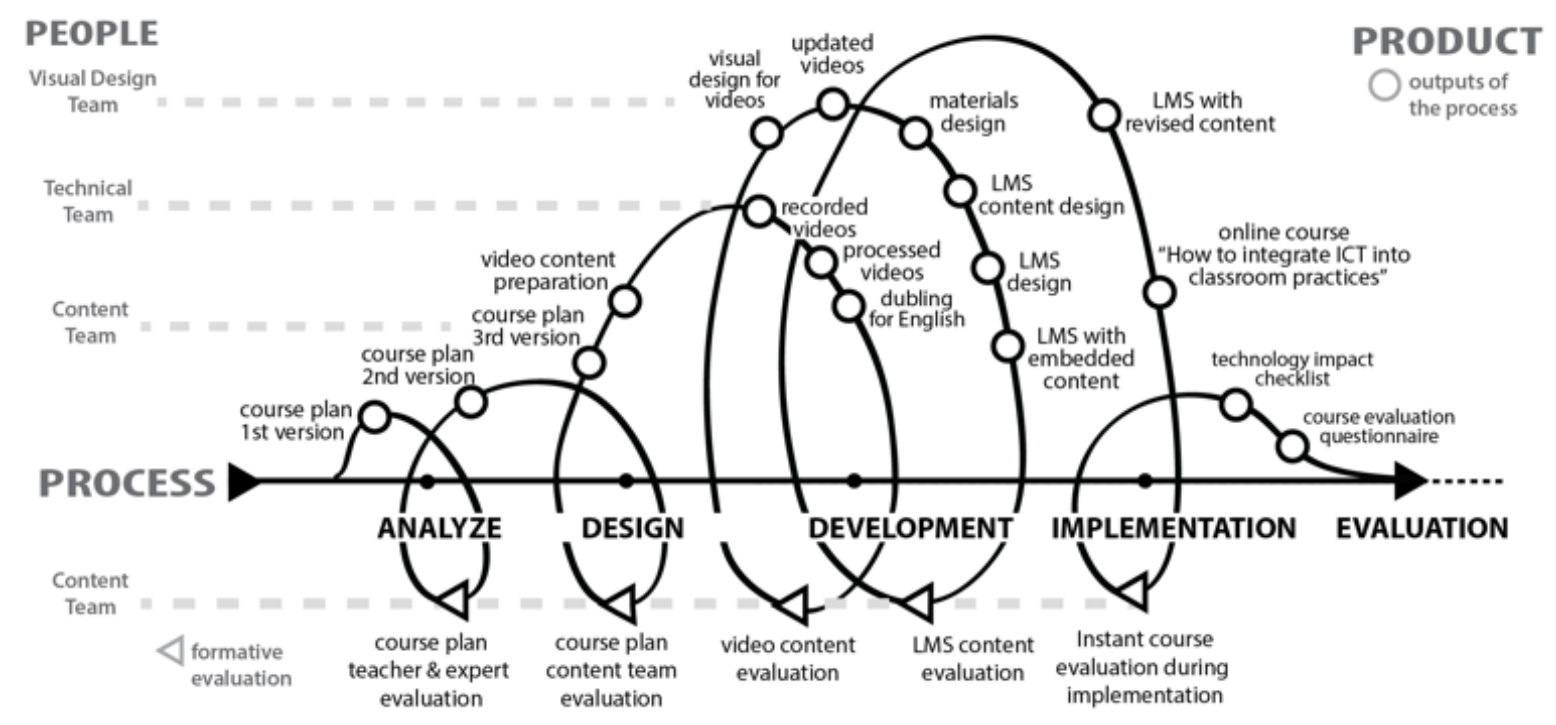

Figure 1. Online course development process

\section{Analysis and Design}

Teacher competencies developed by ISTE, UNESCO, TED, and EC were taken into consideration during the analysis and design phase. The course was designed according to the Tech-PACK model (Roblyer, and Doering, 2013) which combines the Technology, Pedagogy, Content Knowledge (TPACK) model (Koehler \& Mishra, 2005) and the Technology Integration Planning (TIP) model. This model consists of 7 steps under the 3 phases of (1) Analysis of Learning and Teaching Needs, (2) Planning for Integration, and (3) Post-Instruction Analysis and Revisions. The Tech-PACK model was used in the development of the online course's plan, including the topics, educational materials, and learning and assessment activities. 
In addition to a detailed literature review, the opinions of nine teachers that served as representatives of participating schools in six different European countries were gathered during a focus group interview. Focus group participants confirmed the validity of the theoretical base and advised that the course be designed and applied in a manner that allows for implementation in addition to theory. One participant placed emphasis on the importance of interaction in online courses and warned about drop-out rates. Two prominent academicians in the field of Instructional Design whose research focuses on ICT integration were also invited to offer suggestions on the 1 st course plan. One suggested limiting the theoretical portion and focusing on the implementation of participant teachers, as well as removing sections on ethics from the course topics. The second expert suggested adding a part which explains tools that can be used effectively in the learning-teaching process before asking the teachers to develop their own technology-enhanced lesson plans. Another suggestion was to embed the ICT-supported assessment section into previous sections instead of separating it. Both experts highlighted the importance of ICT integration in the pedagogical perspective.

The second version of the course plan was created taking into consideration the feedback from the experts and focus group participants. Two members of the content team then conducted the formative assessment process, the second course plan was revised, and a third plan created. In the third version, the content team reviewed the course from a design perspective, which led them to shorten some of the titles, convert the content a bit, and make the structure more elaborate. The decision was made to develop an online course as a good example of how to integrate ICT into education as well as to give the teachers the opportunity to develop and implement a technology-enhanced lesson plan under the supervision of their instructors and peers. Peer assessment for the technology-enhanced lesson plans developed by the participating teachers was also included in the course plan. It has been shown that the peer assessment process benefits the development of both the receiver of the feedback and the evaluator (Van den Berg, Admiraal, \& Pilot, 2006).

\section{Development}

Video content based on the second course version was created as part of the development phase. The visual design and content development teams collaborated in the creation of videos used in the course. Videos were designed with the speaker occupying half of the screen and images associated with the content in the other half. Video content was examined and evaluated by the content development team. In line with their formative evaluation, videos were processed and finalized by the technical team. English dubbing was carried out for videos shot in the mother tongue of the researchers and trainers as the participants of the course were international. The visual design team designed changing, vectoral, and illustrative visuals associated with the content.

Additional educational materials and activities were prepared after the completion of the videos. Learning management system content was prepared based on the course plan and written explanations of each activity were prepared. The learning management system was then developed by the technical team, the created content was placed in the LMS (Figure 2) and controlled. In addition, links and videos were checked to see if they work. Finally, the LMS was reviewed by the content development and visual design development teams and in line with the evaluation results. 

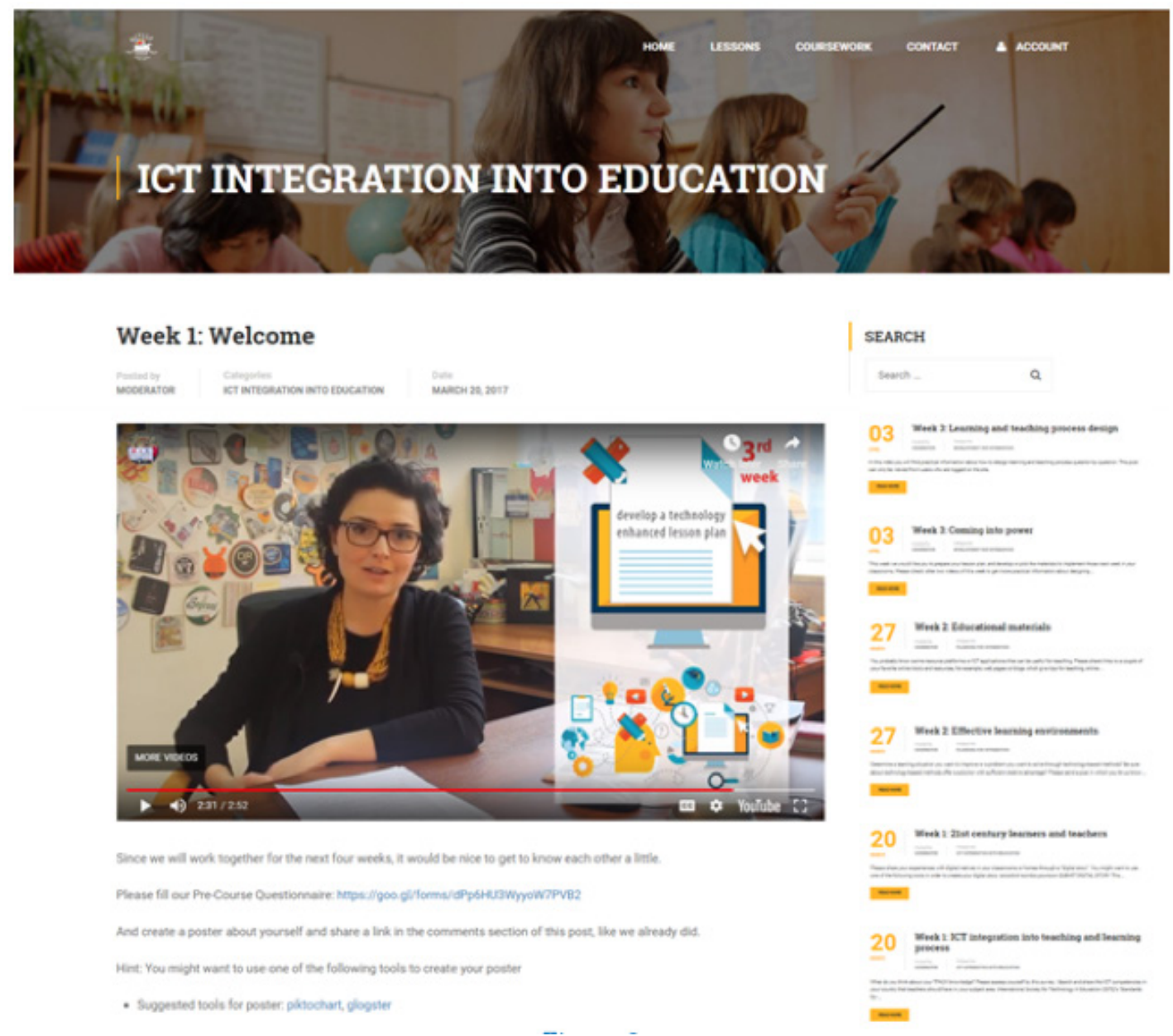

Figure 2. A screenshot of the open online course

\section{Implementation}

Our developed online course entitled "How to integrate ICT into Classroom Practices" was opened to users. During the implementation process, participating teachers were directed to focus on application practices that would enable the integration of technology in education as emphasized in the Tech-PACK model. Activities that facilitate the active learning of the tools were included in the course process in place of passive lessons about technological tools. In this way, teachers were able to learn how to use the tool they chose on their own and then deploy them in their own learning processes. Technological knowledge was put into practice and technology training was provided so that the teachers were enabled to introduce the experience they gained during the training process in their own classrooms. Teachers interacted with colleagues and educators throughout the course by sharing their work and receiving feedback. The course was planned in 4 modules for a duration of 4 weeks. However, the duration of the course was extended in practice by considering the teachers' demands to have longer time for implementation in their own classrooms. During the implementation process, participant problems such as logging into the system or completing a learning activity were monitored. Any e-mails sent from the participants regarding course problems were analyzed in detail by the instructor/researchers.

\section{Evaluation}

In addition to the formative assessments performed during the process in all other steps, the final step was the evaluation step. For the summative evaluation at the end of the implementation, participants were asked to apply the technology-enhanced lesson plans they developed and evaluate the process using a technology impact checklist in an attempt to evaluate the contribution of the online course. Teachers' views on the 
online course were identified in the end-of-course evaluation questionnaire. The online course development process was also evaluated by the instructors using the Rubric for Online Instruction.

The developed "How to integrate ICT into classroom practices" class can be summarized as follows:

\section{Module 1: ICT Integration into Education}

Video 1: Welcome

Sharing 1: Example tools to create your poster

Activity 1: Create your poster for Ice breaking activities

Video 2: ICT integration into teaching and learning process

Sharing 2: International ICT competencies

Activity 2: TPACK survey

Activity 3: Submit ICT Competencies in Your Country

Video 3: 21st century learners and teachers

Sharing 3: Example tools to create your digital story

Activity 4: Create your digital story

\section{Module 2: Planning for Integration}

Video1: Effective learning environments

Activity 1: Determine Learning Situation

Video 2: Educational materials

Sharing 1: Example Tools and Resources

\section{Module 3: Development for Integration}

Video 1: Coming into power

Video 2: Learning and teaching process design

Video 3: Tools in learning and teaching process

Sharing 1: Example lesson plans template

Activity 1: Submit your Lesson Plan and Materials

Sharing 2: Tool Examples

\section{Module 4: Instruction and Reflection}

Activity 1: Assess yourself

Activity 2: Reflection about your lesson

Activity 3: End-of-course evaluation questionnaire

Sharing 1: Certificate

After the course was developed, it was advertised on different websites, social media platforms and through an official notice to the Ministry of Education and teacher volunteers completed a registration form created by the researchers to delineate the study group. A total of 171 teachers from four different European countries were enrolled in the course. Of these, 47 actively participated and made at least one submission. A total of 36 were awarded a certificate upon completion of the course. The study group included the 36 participants who received a certificate. Participant characteristics are summarized in Table 1, based on the registration form data. 
Table 1. Demographic data of the study group

\begin{tabular}{|c|c|c|c|}
\hline & & $\mathrm{n}$ & $\%$ \\
\hline \multirow{4}{*}{ Country } & Turkey & 7 & 20 \\
\hline & Romania & 14 & 37 \\
\hline & Spain & 12 & 34 \\
\hline & Italy & 3 & 9 \\
\hline \multirow{2}{*}{ Gender } & Female & 34 & 94 \\
\hline & Male & 2 & 6 \\
\hline \multirow{3}{*}{ Type of School } & Primary School & 2 & 6 \\
\hline & Secondary School & 15 & 41 \\
\hline & High School & 19 & 53 \\
\hline \multirow{4}{*}{ Subject Matter } & Fine Arts & 1 & 3 \\
\hline & Humanities and Social Sciences & 15 & 42 \\
\hline & Linguistic Sciences & 16 & 44 \\
\hline & Science and Engineering & 4 & 11 \\
\hline \multirow{4}{*}{ Age } & $25-34$ & 5 & 14 \\
\hline & $35-44$ & 16 & 44 \\
\hline & $45-54$ & 11 & 31 \\
\hline & $55-64$ & 4 & 11 \\
\hline \multirow{7}{*}{ Teaching Experience (Year) } & $1-5$ & 4 & 11 \\
\hline & $6-10$ & 5 & 14 \\
\hline & $11-15$ & 5 & 14 \\
\hline & $16-20$ & 10 & 28 \\
\hline & $21-25$ & 5 & 14 \\
\hline & $26-30$ & 3 & 8 \\
\hline & $31-35$ & 4 & 11 \\
\hline \multirow{2}{*}{ Taken a course about technology use in education } & Yes & 30 & 83 \\
\hline & No & 6 & 17 \\
\hline \multirow{2}{*}{ Taken an online course } & Yes & 26 & 72 \\
\hline & No & 10 & 28 \\
\hline \multirow{5}{*}{ ICT literacy rating } & $1-2$ & 1 & 3 \\
\hline & $3-4$ & 5 & 14 \\
\hline & $5-6$ & 10 & 28 \\
\hline & $7-8$ & 14 & 39 \\
\hline & $9-10$ & 6 & 16 \\
\hline
\end{tabular}

The study group was heterogeneous in all respects with the exception of gender (Table 1). In addition, 83\% of participants had previously taken a course on the use of technology in education and $72 \%$ had previous online course experience. The median ICT literacy rate was 7. Accordingly, it can be said that the ICT competencies of the participants were sufficient.

An important feature of the course was its focus on applied practice. During the course, participating teachers implemented technology-enhanced lesson plans and performed self-assessment using the Technology Impact Checklist presented by Roblyer and Doering (2013). The checklist consisted of 11 yes or no questions with an optional comment section for each question. Data were analyzed to answer the second sub-problem of the study. 
At the end of the course, participants completed the End-of-course Evaluation Questionnaire developed by the researchers. The use of an after-course assessment is recommended in the literature for summative purposes (Jones, 2012; O’Neil, Fisher \& Newbold, 2004; Peterson, 2016). Questions were prepared after a review of the literature and in accordance with the objectives of the course. Questions were graded on a scale from "1 - strongly disagree" to "7 - strongly agree". The prepared questions were transferred to the online environment and expert opinion was obtained from five experts on the appearance and content validity of the questions. Yurdugul and Bayrak (2012) suggested to calculate kappa statistics on a case where a small number of experts were reached for investigating content validity. Therefore, kappa statistics were calculated for each item: it was determined that all eight items were appropriate. To determine internal consistency, the Cronbach's Alpha coefficient for the eight Likert questions was calculated as .941. The third sub-problem of this research was addressed by analysis of the questionnaire data.

Course evaluation was performed by the two instructor/researchers using the Rubric for Online Instruction (California State University Chico, 2014). The use of this rubric by the course instructors in order to determine how to update a given course is one of the methods suggested by its developers. The Rubric consists of 25 items under 6 categories: Learner Support \& Resources, Online Organization \& Design, Instructional Design \& Delivery, Assessment $\&$ Evaluation of Student Learning, Innovative Teaching with Technology, and Faculty Use of Student Feedback. Items are graded under the triple scale of "baseline", "effective", and "exemplary". The instructor/researchers performed a joint evaluation of the course using the Rubric for Online Instruction.

As can be seen in Figure 1, data were collected online at the end of the lesson using the Technology Impact Checklist, End-of-course Evaluation Questionnaire and Rubric for Online Instruction. Descriptive statistics were used to describe the data and data was reported as percentage, frequency, and medians. Additionally, optional comments filled in by participants after the items of Technology Impact Checklist were presented.

\section{FINDINGS}

\section{Self-assessment of Teachers on Their Implementation}

A total of 35 teachers completed the Technology Impact Checklist after preparing and implementing their lesson plans. According to the results of their self-assessments, participants rated their implementation as "high" in items 2, 4, and 6, "intermediate" in items 1, 3, 7, and 8, and relatively "low" in items 5, 9, 10, and 11 (Table 2). Any optional comments given were also reviewed and reported. 
Table 2. Self-assessment of teachers on their implementation via technology impact checklist

\begin{tabular}{|c|c|c|c|}
\hline \multirow{2}{*}{\multicolumn{2}{|c|}{ Technology impact checklist items }} & \multicolumn{2}{|c|}{$\%$} \\
\hline & & \multirow[t]{2}{*}{ Yes } & \multirow[t]{2}{*}{ No } \\
\hline \multicolumn{2}{|c|}{ How Do You Know When You Have Integrated Technology Well? } & & \\
\hline 1 & An outside observer sees the technology activity as a seamless part of the lesson. & 68.57 & 31.43 \\
\hline 2 & The reason for using the technology is obvious to you, the students, and others. & 100 & 0 \\
\hline 3 & The students are focusing on learning, not on the technology. & 74.29 & 25.71 \\
\hline 4 & You can describe how technology is helping a particular student. & 91.43 & 8.57 \\
\hline 5 & $\begin{array}{l}\text { You would have difficulty accomplishing lesson objectives if the technology } \\
\text { weren't there. }\end{array}$ & 57.14 & 42.86 \\
\hline 6 & $\begin{array}{l}\text { You can explain easily and concisely what the technology is supposed to } \\
\text { contribute. }\end{array}$ & 100 & 0 \\
\hline 7 & All students are participating with the technology and benefiting from it. & 77.14 & 22.86 \\
\hline \multicolumn{4}{|c|}{ How Do You Know When You Have Not Integrated Technology Well? } \\
\hline 8 & You consistently see the technology as more trouble than it is worth. & 31.43 & 68.57 \\
\hline 9 & $\begin{array}{l}\text { You have trouble justifying cost and preparation time in terms of benefits to your } \\
\text { students. }\end{array}$ & 48.57 & 51.43 \\
\hline 10 & $\begin{array}{l}\text { Students spend more time trying to make the technology work than on learning } \\
\text { the topic. }\end{array}$ & 48.57 & 51.43 \\
\hline 11 & The problem you were trying to address is still there. & 42.86 & 57.14 \\
\hline
\end{tabular}

All teachers stated that the reason why technology is used in the learning process was clearly perceived by both themselves and the students (item 2) and that they could easily and briefly explain how the technology would contribute to the learning process (item 6).

"With the help of technology, students work more effectively while having fun of the thing they have done compared to the traditional paper studies." (T17)

"Yes, because it is a modern / current teaching and offers a multitude of opportunities / facilities to develop the students' skills desired." (T34)

Technology contributes to make students select, organize and present the required information. (T3)

The technology motivates them and helps them to find and present the information in a more attractive form. (T10)

As a teacher, I don't want to be the only source of knowledge, learning or help. Technology helps my students understand subjects and explore the universe or their own skills better. (T13)

Almost all teachers (91.43\%) stated that they could explain how technology helped students (item 4). Of those, $31.25 \%$ associated this with student motivation and reported that the technology makes the learning process more interesting and effective.

"I could observe how technology motivated students who find difficult my subjects: geography and history."

"The technology motivates him and helps him to find and present the information in a more attractive form." (T8)

"When the teacher uses technology, he makes his lessons more interesting for all the students." (T22)

"Technology helps teachers to teach in a visual way. Students don't forget easily when they use technology." (T18)

"The students don't want to read or listen to a classical lesson, so if we use technology they become interested." (T27) 
Three-quarters (74.29\%) of participants stated that their students were focused on learning rather than on technology during the learning-teaching process (item 3).

"Students are focused on learning and technology can enrich learning experiences and gives them the opportunity to make connections with the real world, to find resources, and create products." (T9)

According to $77.14 \%$ of the teachers, all students interacted with and benefited from technology (item 7) while $68.57 \%$ stated that technology was an integral part of the process (item 1) and that it contributed to the teaching process rather than being a problem (item 8).

"When we plan our lesson well, technology doesn't cause more trouble." (T13)

"if we use technology correctly, it will be useful." (T18)

"If the lesson is not carefully planned technology could result in a waste of time." (T5)

"ICT integration is more to do and learn for teachers but it's worth it." (T32)

On the necessity of the use of technology, $57.4 \%$ of participants reported that they would have had difficulty in achieving the learning objectives without technology (item 5) while $25 \%$ of these teachers related these views with the harmony between the learning objective and the content and technology. They also emphasized that the contribution of technology differed according to certain situations.

"Absolutely right. As an EFL teacher, if I don't use technology in my classes my students won't be able to learn well, practice, or revise so often." (T13)

"Well, sometimes it's very useful, but not always, when teaching literature." (T33)

Half of the teachers (51.43\%) stated that providing the necessary time and budget for the use of technology in the learning process was not a problem (item 9). T2 and T3 stated that although it required more time, the use of technology is necessary and worth the effort.

"It is a requirement and I rather prefer to see how my students learnt rather than worry about spending time." (T2)

"I am really satisfied with the student's efforts to complete the task. I would not change the activity although it means much more work for me." (T3)

The same percentage of teachers (51.43\%) agreed that students were focused on learning rather than technology (item 10) and $57.14 \%$ reported that they were able to solve their target learning problem using technology (item 11). Conversely, thinking that students focus on technology rather than content, T7 stated that learning to use a new tool requires a significant amount of time and concentration.

"Using a web tool for the first time requires a lot of time and concentration." (T7)

T10, who, similar to T7, discussed how technology required time, added that they could produce solutions to this problem by extending the working time.

"In some moments, but we solved adding more time to work." (T10)

T15 stated that technology caused problems rather than contributing to solving the problem and that the use of technology required more time whereas T16 expressed that the learning outcomes were better with the use of technology.

"They may spend more time but learn better. For example, they play games and they learn vocabulary and daily language better. I think it gives them a chance to explore something by themselves." (T15)

"Although they learn it better." (T16) 


\section{End-of-Course Evaluation}

In order to determine the effect of the developed course, the End-of-course Evaluation Questionnaire consisting of 8 questions and scaled from 1 to 7 was answered by the participants at the end of the course $(\mathrm{n}=35)$. Since the answers are at ordinal level of scale, both percentage and median values are reported in Table 3 .

Table 3. Results of Teachers' End-Of-Course Evaluation (percentages and medians)

\begin{tabular}{|c|c|c|c|c|c|c|c|c|c|}
\hline & & $\begin{array}{c}1 \\
(\%)\end{array}$ & $\begin{array}{c}2 \\
(\%)\end{array}$ & $\begin{array}{c}3 \\
(\%)\end{array}$ & $\begin{array}{c}4 \\
(\%)\end{array}$ & $\begin{array}{c}5 \\
(\%)\end{array}$ & $\begin{array}{c}6 \\
(\%)\end{array}$ & $\begin{array}{c}7 \\
(\%)\end{array}$ & Median \\
\hline 1 & $\begin{array}{l}\text { The course objectives and } \\
\text { expectations were clear. }\end{array}$ & 3 & 0 & 0 & 3 & 9 & 40 & 46 & 6 \\
\hline 2 & $\begin{array}{l}\text { I gained an understanding of ICT } \\
\text { integration into education. }\end{array}$ & 0 & 0 & 3 & 3 & 17 & 34 & 43 & 6 \\
\hline 3 & $\begin{array}{l}\text { I developed skills or learned } \\
\text { concepts that I can apply to my } \\
\text { classroom. }\end{array}$ & 0 & 0 & 0 & 11 & 14 & 26 & 49 & 6 \\
\hline 4 & $\begin{array}{l}\text { I am able to think more critically } \\
\text { or deeply about ICT integration } \\
\text { into education. }\end{array}$ & 0 & 0 & 0 & 9 & 26 & 40 & 26 & 6 \\
\hline 5 & The course met my expectations. & 3 & 0 & 3 & 3 & 23 & 26 & 43 & 6 \\
\hline 6 & $\begin{array}{l}\text { The course tasks helped me } \\
\text { to improve myself about ICT } \\
\text { integration into education. }\end{array}$ & 0 & 3 & 0 & 0 & 11 & 31 & 54 & 7 \\
\hline 7 & $\begin{array}{l}\text { Videos and other course materials } \\
\text { were helpful to understand ICT } \\
\text { integration into education. }\end{array}$ & 3 & 0 & 3 & 3 & 14 & 40 & 37 & 6 \\
\hline 8 & $\begin{array}{l}\text { The course provided enough } \\
\text { opportunities for me to } \\
\text { demonstrate what I had learned. }\end{array}$ & 0 & 3 & 0 & 6 & 17 & 37 & 37 & 6 \\
\hline
\end{tabular}

The median value of all but one question was 6 while the question on whether the course tasks helped improve participants" ability to integrate ICT in education received a mean score of 7 . In addition to the questions in Table 3, the participants were asked whether they suggested this course to other educators. Only one participant responded negatively to this question while the other 34 said they would suggest the course to other educators, suggesting that the course was successful.

\section{Instructor Evaluation}

The course evaluation provided by the two instructor/researchers using the Rubric for Online Instruction is given in Table 4. Scores were given as "baseline", "effective", and "exemplary". Comments were mostly provided on items that did not receive full scores and suggestions for the improvement of the course were given.

A score of "effective" was given to the presentation of resources and content to support different learning abilities in the "Learner Support \& Resources" category. Despite numerous undertakings, further efforts to provide a variety of course-specific resources are needed. 
In the online Organization \& Design category, a full score of "exemplary" was given as the course was believed to be well-organized. The amount of time allocated to the analysis, design, and development phases was believed to strengthen the course in this respect. In addition, the orientation video was evaluated as effective in providing adequate information and expectations. In the category of Instructional Design \& Delivery, the item that did not receive a full score was that of "offering interaction and communication student to student, student to instructor and student to content". It was concluded that the course did not allow for intense student-instructor interaction due to the chosen WordPress infrastructure and preferred strategy.

All questions in the Assessment \& Evaluation of Student Learning category were determined to have "effective" values. Full scores were not given as evaluations were not performed on several occasions and continuous feedback was not received throughout the course period. While peer-review was encouraged and feedback provided to several teachers, not all participants received/gave feedback on a weekly basis. On the other hand, as assignments were seen by all participants, the feedback provided could be considered by other teachers. The feedback was particularly centered during the course plan development and implementation weeks. Each teacher's plan received feedback from one instructor and two peers. In this context, this category was determined to be "effective".

The categories of Innovative Teaching with Technology and the Faculty Use of Student Feedback did not receive full scores on all items for similar reasons to those described above. A sufficient level of innovative technology was used for communication and learning, and new teaching methods were utilized. However, this did not reach the level of a "variety of technology", and therefore the course was considered to be at the "effective" level in the Innovative Teaching with Technology category.

Participant evaluations in the Faculty Use of Student Feedback category were taken only at the end of the course. While the remarks conveyed as messages during the course process were also taken into account, no multiple opportunities were provided for the students to give feedback on the course.

Table 4. Instructors' remarks regarding the online course

\begin{tabular}{lccc}
\hline Categories & Baseline & Effective & Exemplary \\
\hline Learner Support \& Resources (3 criteria) & 0 & 1 & 2 \\
Online Organization \& Design (5 criteria) & 0 & 0 & 5 \\
Instructional Design \& Delivery (5 criteria) & 0 & 1 & 4 \\
Assessment \& Evaluation of Student Learning (5 criteria) & 0 & 5 & 0 \\
Innovative Teaching with Technology (4 criteria) & 0 & 4 & 0 \\
Faculty Use of Student Feedback (3 criteria) & 0 & 2 & 1 \\
\hline
\end{tabular}

\section{DISCUSSIONS AND CONCLUSION}

Teachers and their professional development are among the most important elements determining the success of the integration of technology in the education process. Although many professional training opportunities are provided in this direction, the literature shows that these trainings remain theoretical and do not allow teachers to implement the integration in which they are instructed. Therefore, any professional development should include hands-on training. This requirement has been emphasized in various competencies developed by different institutions and organizations such as UNESCO (2011), ISTE (2008), TED (2009), EC (2017).

Furthermore, teaching technology alone does not provide a sufficient point of view in terms of providing technology integration into education. Technology is a tool that changes every day, necessitating the ability to select the appropriate tools and follow a holistic perspective to improve teaching. In line with this, the focus of the current study is the open online course entitled "How to integrate ICT into classroom practices" developed to emphasize practical integration based on the Tech-PACK Model (Roblyer \& Doering, 2013). 
The prominent aim part of the course was to support teachers to develop a technology-enhanced lesson plan for teachers in their classrooms and to support this process with feedback from both peers and instructors. In addition, participating teachers were able to use the discussed technologies in a context that serves their own learning.

The aim of this study was to design and then evaluate the implementation of an online professional development program to fill the gap in the literature. The study was carried out using the design-based research method. Evaluation of the developed course was performed based on the self-assessment of the participants about the practices in their classes, end-of-course evaluation questionnaire answers, and the results of an evaluation performed by the instructors who conducted the online course.

Teacher self-assessment of technology-enhanced applications is considered to be an important indicator of evaluation of the online course, beyond being an important part of their learning processes. In our course, participants were asked to question the extent to which they could integrate technology and their strengths or weaknesses in their self-assessment. Self-assessment results showed teachers rated themselves as strong in technology-enhanced course planning but weaker when it came to the practical application due to the many variables involved in the process. Teachers stated that they could easily explain the possible contributions of technology to the teaching and learning process and could easily justify a technology-enhanced structure to create a lesson plan. They stated that they were not as strong in the classroom as in the planning stage and they focused on learning rather than technology as an integral part of the learning process. However, even when the difficulties in implementation and the need for additional time are considered, more than half of the teachers agreed that the use of technology is an advantage. Teachers' experience with the instructor and colleague feedback in relation to the relationship between planning and implementation was the most important gain for them during the course.

Based on the end-of-course evaluations, teachers reported that they gained awareness and skills about ICT integration, the content clear and understandable, the course met their expectations, and the course materials and tasks were useful. In addition, participants had the opportunity to show what they learned. Based on these results, it can be said that the objectives of the course were achieved within the limitations of the study. In addition, $97 \%$ of the participants suggested the course to others, indicative of their satisfaction with the course (Contreras-Castillo, Favela, Pérez-Fragoso \& Santamaria-del-Angel, 2004; Endres, Chowdhury, Frye $\&$ Hurtubis, 2009).

Following its completion, the instructor/researchers evaluated the course using the 6-category Rubric for Online Instruction. The Learner Support \& Resources (2.60 / 3.00), Online Organization \& Design $(3.00$ / 3.00), and Instructional Design \& Delivery (2.80 / 3.00) categories scored as "exemplary", the top value of the rubric, while the Assessment \& Evaluation of Student Learning (2.00 / 3.00), Innovative Teaching with Technology (2.00 / 3.00), and Faculty Use of Student Feedback (2.33 / 3.00) were evaluated as "effective", the intermediate value of the rubric. The quality of the analysis, design, and development process of the course was considered as the reasons for the full score in the Online Organization \& Design category.

Items that did not receive full points were not the result of mistakes made during implementation but of preferences made during the course design stage. It was not possible to know ahead of time the number of teachers that would participate in an open course and thus considering the limited number of instructors, a plan that would allow for an intense student-instructor interaction was not devised. Although it is known that satisfaction with online learning is directly related to such interaction, it is usually not possible to provide it in massive open online courses. Peer assessment is preferred in MOOCs and it is a suitable strategy for the teacher to provide feedback on some student assignments which can be followed by all participants (Huisman, Admiraal, Pilli, van de Ven, \& Saab, 2018; Suen, 2014). A similar strategy was adopted in our course and weekly activity assignments were posted on the course platform to allow all participants access and some assignments received feedback from the instructors. In addition, instructors prepared and shared an assignment for each activity (For example a digital story about the lives of 21 st century students) in order to close the feedback gap. On the other hand, feedback from two peers and one instructor was provided on the technology-enhanced lesson plans that were to be implemented and developed by the teachers, which is thought to be the most powerful part of the course. Therefore, the Assessment $\&$ Evaluation of Student Learning and the Innovative Teaching with Technology categories were rated "effective". 
Since the participant feedback on the course was collected only at its completion, the Faculty Use of Student Feedback category was similarly considered to be "effective". However, this might be due to the fact that the course process was planned over a duration of only 4 weeks, a relatively short period of time, to allow for feedback for the planning of the rest of the course. Considering that the developer of the rubric is a university, one semester was taken as the duration of the course and mentioned in the rubric items.

The implementation of the "How to integrate ICT into classroom practices" open online course was evaluated from different perspectives. The evaluations concluded that the next implementation of the course should aim to improve the online interaction and the extent of classroom application by the teachers. First, greater student-instructor interaction can be achieved by taking the instructor's workload into account and organizing live classes in set time periods. The feedback based on performed activities can be provided during these live classes to enable more participants to benefit. Interactive videos would increase student-content interaction. Additionally, the inclusion of different e-measurement tools in the learning process would allow participants to evaluate their learning. The addition of activities that can be performed jointly and the use of collaborative web tools and peer feedback could be encouraged not only for the lesson plans but for each activity to encourage greater student-student interaction. The LMS used to increase the interaction may need to be replaced or supported by plug-ins that allow for more communication. In addition to system interaction, it would be appropriate to further strengthen the application, which is an important aspect of the course. To achieve this, the application module of the course should be planned for a longer-term and with a repeating structure and the teachers' performance of at least one more practice in the classroom would be a significant improvement. A recent meta-analysis study of 30 studies on online learning courses by Castro and Tumibay (2019) report similar suggestions, particularly those on interaction and formative feedback. We believe that the efficiency of the course will increase with these planned improvements.

Authors' Note: The "How to integrate ICT into classroom practices" open online course was funded by the Erasmus+ Program of the European Union as a part of the project "Searching for the Labours of Hercules" (2014-1-TR01-KA201-012990).

\section{BIODATA and CONTACT ADDRESSES of AUTHORS}

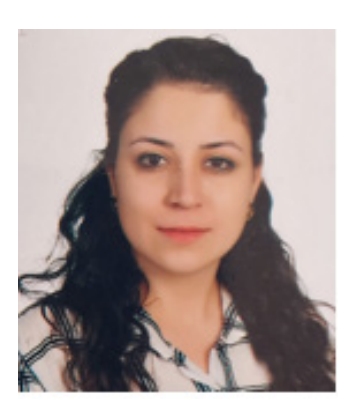

Bengusu UGUR is an information technology (IT) teacher at Ulker Yorukoglu Science and Art Center. She worked in different secondary and high schools before moving into Science and Art Center. Following her bachelors' degree, she received her M.Sc. in Computer Education and Instructional Technology at Hacettepe University. Her research mainly focuses on ICT integration into learning and teaching process. She organizes game-based block coding teacher trainings under the Ministry of National Education. She has project experience in Erasmus+ and Tubitak projects.

Bengusu UGUR

Department of Computer Education and Instructional Technology, Education Faculty

Address: Hacettepe University Beytepe Campus, 06800, Ankara, Turkey

Phone: +90 3122977176,

E-mail: bengusu.ugur@hacettepe.edu.tr 


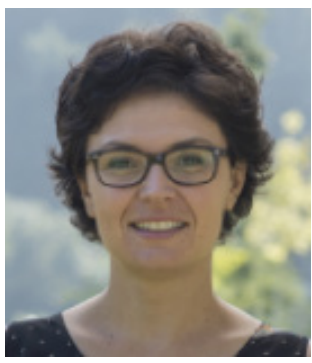

Selay ARKUN KOCADERE is an associate professor at Hacettepe University. Following her bachelors' degree in Mathematics Education, she received her M.Sc. and Ph.D. in Computer Education and Instructional Technology. Dr. Kocadere worked as an instructional designer in the private sector for two years before moving into academics. Interested in technology enhanced mathematics education, online learning, and mentoring, Dr. Kocadere's recent research focuses on gamification and educational games. Currently, she manages one national and two international projects on distance education, and gamification.

\section{Selay ARKUN KOCADERE}

Department of Computer Education and Instructional Technology, Education Faculty Address: Hacettepe University Beytepe Campus, 06800, Ankara, Turkey

Phone: +903122977176

E-mail: selaya@hacettepe.edu.tr

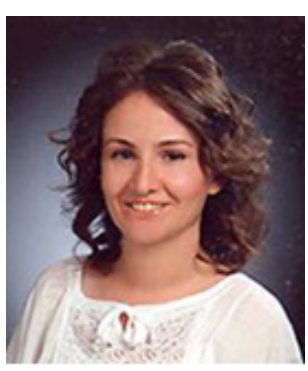

Pinar NUHOGLU KIBAR, Ph.D., is a researcher in the Department of Computer Education and Instructional Technology of Faculty of Education at Hacettepe University. Dr. Kibar holds MSc and Ph.D. in Computer Education and Instructional Technology from Hacettepe University. Her research interests include e-learning, multimedia learning, visualization in education, knowledge and information visualization, visual literacy. Highly interested in educational infographics, Dr. Kibar focuses on improving the infographic creation process of leaners during learning and teaching process. She currently studies on interactive and dynamic form of infographic design in the learning process, which covers animation, video and dashboards design.

\section{Pinar NUHOGLU KIBAR}

Department of Computer Education and Instructional Technology, Education Faculty Address: Hacettepe University Beytepe Campus, 06800, Ankara, Turkey

Phone: +90 3122977176

E-mail: pnuhoglu@hacettepe.edu.tr

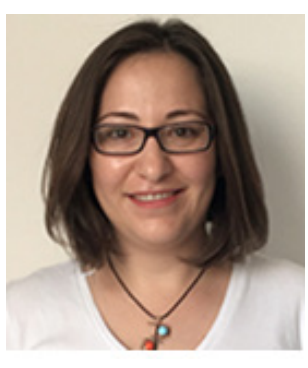

Fatma BAYRAK is an assistant professor at Computer Education and Instructional Technologies, Hacettepe University. Dr. Bayrak gained her Ph.D. in Computer Education and Instructional Technologies at July, 2014. Her academic interest areas are e-learning, assessment in online learning, technology enhanced assessment, feedback and reflective thinking. In addition to the lectures she has given, she has been a researcher in national and international projects. Over the years, she has written various articles and book chapters, participated in national and international conferences.

Fatma BAYRAK

Department of Computer Education and Instructional Technology, Education Faculty

Address: Hacettepe University Beytepe Campus, 06800, Ankara, Turkey

Phone: +90 3122977176

E-mail: fbayrak@hacettepe.edu.tr 


\section{REFERENCES}

Almenara, J. C., \& Gimeno, A. M. (2019). Information and Communication Technologies and initial teacher training. Digital models and competences. Profesorado-Revista De Curriculum Y Formacion De Profesorado, 23(3), 247-268.

Anderson, T., \& Shattuck, J. (2012). Design-based research: a decade of progress in education research?. Educational Researcher, 41(1), 16-25. https://doi.org/10.3102/0013189X11428813

Arkun Kocadere, S. (2017). Integration of ICT into Education within the Framework of an Erasmus+ Project. In: Yasemin Usluel (Ed.), Various Aspects of ICT Integration in Education (pp. 465 - 484), Gazi Kitabevi, Ankara.

Atman Uslu, N., \& Usluel, Y. K. (2019). Predicting technology integration based on a conceptual framework for ICT use in education. Technology, Pedagogy and Education, 28(5), 517-531.

Ayaz, M. F., Oral, B., \& Soylemez, M. (2015). Evaluation of the post-graduate theses on teacher education in Turkey. Elementary Education Online, 14(2), 787-802. http://dx.doi.org/10.17051/io.2015.89009

Bakker A., \& Van Eerde D. (2015). An Introduction to design-based research with an example from statistics education. In: A. Bikner-Ahsbahs, C. Knipping, \& N. Presmeg (eds.) Approaches to qualitative research in mathematics education. Advances in Mathematics Education (pp. 429-466). Springer, Dordrecht. https://doi.org/10.1007/978-94-017-9181-6_16

Barab, S., \& Squire, B. (2004). Design-based research: putting a stake in the ground. Journal of the Learning Sciences, 13(1), 1-14. https://doi.org/10.1207/s15327809jls1301_1

Beglau, M., Craig-Hare, J., Foltos, L., Gann, K., James, J., Jobe, H., ... \& Smith, B. (2011). Technology, coaching, and community: Power partners for improved professional development in primary and secondary education. Retrieved from https://www.ri-iste.org/Resources/Documents/Coaching Whitepaper_digital.pdf

Blikstad-Balas, M., \& Klette, K. (2019). Still a long way to go. Nordic Journal of Digital Literacy, 15(01), 55-68.

California State University Chico (2014). Rublic for Online Instruction. Retrieved from https://bit. ly/2W0bGFl

Castro, M.D.B., Tumibay, G.M. (2019). A literature review: efficacy of online learning courses for higher education institution using meta-analysis. Education and Information Technologies. https://doi. org/10.1007/s10639-019-10027-z

Contreras-Castillo, J., Favela, J., Pérez-Fragoso, C., \& Santamaria-del-Angel, E. (2004). Informal interactions and their implications for online courses. Computers \& Education, 42(2), 149-168. https://doi. org/10.1016/S0360-1315(03)00069-1

Dede, C., Jass Ketelhut, D., Whitehouse, P., Breit, L., \& McCloskey, E. M. (2009). A research agenda for online teacher professional development. Journal of Teacher Education, 60(1), 8-19. https://doi. org/10.1177/0022487108327554

Edelson, D. C. (2002). Design research: What we learn when we engage in design. The Journal of the Learning sciences, 11(1), 105-121. https://www.cs.uic.edu/ i523/edelson.pdf

Endres, M. L., Chowdhury, S., Frye, C., \& Hurtubis, C. A. (2009). The multifaceted nature of online MBA student satisfaction and impacts on behavioral intentions. Journal of Education for Business, 84(5), 304-312. https://doi.org/10.3200/JOEB.84.5.304-312

Evans, S. A. (2006). A validation study of a measurement of technology integration skills for pre-service teachers. (Doctoral dissertation, The University of North Carolina at Charlotte) Retrieved from https://www.learntechlib.org/p/121000/

Forkosh-Baruch, A., \& Avidov-Ungar, O. (2019). ICT Implementation in Colleges of Education: A Framework for Teacher Educators. Journal of Information Technology Education, 18, 207-229. 
Gao, P., Tan, S. C., Wang, L., Wong, A., \& Choy, D. (2011). Self reflection and preservice teachers' technological pedagogical knowledge: Promoting earlier adoption of student-centred pedagogies. Australasian Journal of Educational Technology, 27(6), 997-1013. https://doi.org/10.14742/ajet.925

Guskey, T. R. (2007). Results-oriented professional development. In: A. C. Onstein, E. F. Pajak and S. B. Ornstein (eds.), Contemporary issues in curriculum (pp. 334-346), Pearson Education, Boston.

Hanover Research (2014). Professional development for technology integration. Retrieved from https:// ts.madison.k12.wi.us/files/techsvc/Professional Development for Technology Integration.pdf

Hew, K. F. \& Brush, T. (2007). Integrating technology into K-12 teaching and learning: current knowledge gaps and recommendations for future research. Education Tech Research Dev, 55(3), 223-252. https://doi.org/10.1007/s11423-006-9022-5

Herzig, R. G. M. (2004). Technology and its impact in the classroom. Computers \& Education, 42(2), 111 131. http://dx.doi.org/10.1016/S0360-1315(03)00067-8

Huisman, B., Admiraal, W., Pilli, O., van de Ven, M., \& Saab, N. (2018). Peer assessment in MOOCs: The relationship between peer reviewers' ability and authors' essay performance. British Journal of Educational Technology, 49(1), 101-110. https://doi.org/10.1111/bjet.12520

Ifinedo, E., Rikala, J., \& Hamalainen, T. (2020). Factors affecting Nigerian teacher educators' technology integration: Considering characteristics, knowledge constructs, ICT practices and beliefs. Computers \& Education, 146, 103760.

International Society for Technology in Education (ISTE). (2008). National Educational Technology Standards (NETS) for teachers. Retrieved from https://bit.ly/2SwYZ1R

International Society for Technology in Education (ISTE). (2012). National Educational Technology Standards (NETS) for teachers. Retrieved from https://bit.ly/2GbdUJa

Jones, S. J. (2012). Reading between the lines of online course evaluations: identifiable actions that improve student perceptions of teaching effectiveness and course value. Journal of Asynchronous Learning Networks, 16(1), 49-58. Retrieved from https://bit.ly/2T5ghYN

Kaya, G., \& Kocak Usluel, Y. (2012). Content analysis of factors affecting ICT integration in teachinglearning process. Journal of Buca Faculty of Education, 31, 48-67. Retrieved from https://bit. ly/2NwGvNQ

Khan, B. H. (Ed.). (2005). Managing e-learning: Design, delivery, implementation, and evaluation. IGI Global.

Koehler, M. J., \& Mishra, P. (2005). What happens when teachers design educational technology? The development of technological pedagogical content knowledge. Journal of educational computing research, 32(2), 131-152. https://doi.org/10.2190/0EW7-01WB-BKHL-QDYV

McKenney, S., \& Reeves, T. C. (2012). Conducting educational design research. Routledge.

O’Neil, C. A., Fisher, C. A., \& Newbold, S. K. (2004). Developing an online course: best practices for nurse educators. Springer Publishing Company.

Peterson, J. L. (2016). Formative evaluations in online classes. Journal of Educators Online, 13(1). Retrieved from https://bit.ly/2zErnFv

Pierson, M. E. (2001). Technology integration practice as a function of pedagogical expertise. Journal of Research on Computing in Education, 33(4), 413- 430. https://doi.org/10.1080/08886504.2001. 10782325

Prestridge, S., \& Tondeur, J. (2015). Exploring elements that support teachers' engagement in online professional development. Education Sciences, 5(3), 199-219.

Redecker, C. (2017). European Frameworkfor the Digital Competence of Educators: DigCompEdu. Y. Punie, (ed.). Publications Office of the European Union, Luxembourg. https://dx.doi.org/10.2760/159770

Roblyer, M. D., \& Doering, A. H. (2013). Integrating educational technology into teaching. Pearson New International Edition. Pearson Higher Ed. 
Stein, H., Gurevich, I., \& Gorev, D. (2020). Integration of technology by novice mathematics teachers-what facilitates such integration and what makes it difficult?. Education and Information Technologies, 25(1), 141-161.

So, H. J. \& Kim, B. (2009). Learning about problem based learning: Student teachers integrating technology, pedagogy and content knowledge. Australasian Journal of Educational Technology, 25(1), 101-116. https://doi.org/10.14742/ajet.1183

Suen, H. K. (2014). Peer assessment for massive open online courses (MOOCs). International Review of Research in Open and Distributed Learning, 15(3), 312-327. http://www.irrodl.org/index.php/ irrodl/article/view/1680/2904

Tondeur, J., Forkosh-Baruch, A., Prestridge, S., Albion, P., \& Edirisinghe, S. (2016). Responding to challenges in teacher professional development for ICT integration in education. Educational Technology \& Society, 19(3), 110-120.

Turk Egitim Dernegi (TED) (2009). Ogretmen yeterlikleri [Teacher competencies]. Turk Egitim Dernegi. Retrieved from https://bit.ly/2IGfKrF

Ugur, B. \& Arkun Kocadere, S. (2016). Ogrenme ve ogretme surecine BIT entegrasyonu: Bir cevrimici ogretmen egitimi onerisi [ICT integration into the learning and teaching process: An online teacher training proposal]. XVIII. Akademik Bilisim Konferansi (AB16) Proceedings. Retrieved from https://ab.org.tr/ab16/bildiri/290.pdf

Usluel, Y. K. (2016). Teknolojinin ogrenme-ogretme surecine entegrasyonu [ICT integration into learningteaching process]. In I. Unal, Y. ve Kocak Usluel (Ed.), Prof. Dr. Mustafa Aydin'a Armagan Egitim Bilimleri Yazilari (pp. 321-338). Ankara: Gazi Kitabevi.

Peterson, J. L. (2016). Formative evaluations in online classes. Journal of Educators Online, 13(1). Retrieved from https://bit.ly/2IGfKrF

UNESCO (2011). UNESCO ICT Competency framework for teachers. P. Hine (ed) Retrieved from https:// bit.ly/2V9TuYC

Usluel, Y. K., Mumcu, ,F. K., \& Demiraslan Y. (2007). ICT in the learning-teaching process: teachers' views on the integration and obstacles. Hacettepe University Journal of Education, 32, 164-179. Retrieved from https://bit.ly/2U7DOF0 